To cite this article: Jovanelis Ariesto Jugawan, Marvina, Wilhelmus Hary S (2021). THE TRANSFORMATIONAL LEADERSHIP AND TRUST TO DEVELOP DIGITALIZE EMERGING MARKET AND THE FINANCIAL PERFORMANCE HI-TECH MULTI-NATIONAL CORPORATION, International Journal of Research in Commerce and Management Studies (IJRCMS) 3 (6): 83-92

\title{
THE TRANSFORMATIONAL LEADERSHIP AND TRUST TO DEVELOP DIGITALIZE EMERGING MARKET AND THE FINANCIAL PERFORMANCE HI-TECH MULTI- NATIONAL CORPORATION
}

\author{
Jovanelis Ariesto Jugawan, Marvina, Wilhelmus Hary S* \\ MM FEB University of Persada Indonesia Y.A.I \\ DOI: http://dx.doi.org/10.38193/IJRCMS.2021.3606
}

\begin{abstract}
An among multi-national- firms have the misguide from the vision and missions on the heterogeneousindustrial, costly, less-information fail from the tight competitions, no-data supported and the radically inventions. This analysis would be investigating the research gap within the multi-national-hi-tech venture. The novelty research- result from the development of emerging market that more contribution on body of knowledge of the R-A theory, GST and the theory of the GOF, that with to develop within the analysis of industrial hi-tech firms. Moreover, the research method was using the predicted strategy in multivariate data analysis within an among the latent variables with the SmartPLS.
\end{abstract}

KEYWORDS: Transformational Leadership, Trust, Multi-National- firms, digitalize emerging market, financial performance.

\section{INTRODUCTION}

The determinant factors within digitalize market and financial performance on hi-tech national firms have some indicated as follow; less informational and costly, the digital- channel consumer engagement, the rigor competitions, provide some big data, weak leadership, the human resources, market oriented and incremental innovations that have been could be confirm result of wide research on the world (Graça, Barry, \& Doney, 2016; Hau, Evangelista, \& Thuy, 2013; Shelby, 2007) (Vivek, Beatty, \& Morgan, 2012),(Hollebeek, 2012), (Harrigan, Evers, Miles, \& Daly, 2017), (Bitter \& Grabner-Kräuter, 2016), (Glińska-Neweś, Sudolska, Karwacki, \& Górka, 2017; Haifen, Mengya, \& Jingqin, 2017; J. Hamilton, 2009; Straker \& Wrigley, 2016).

Moreover, an inquiry have the low-process of the impact to the financial performance and the meaning in the entire hi-tech national- firms as the result research from some scholars synthesis and contribution on body of knowledge, that some research gap that must be fulfill the novelty variables as the new models of the emerging market- based research within the customer trust as the moderating variables.(Bürkner \& Lange, 2017; Darren, 2015; González, Rodríguez Gil, Martorell Cunill, \& 
Vol. 3, No. 06 Nov-Dec; 2021 Page. No. 83-92

Merigó Lindahl, 2016; Ho, Nguyen, Adhikari, Miles, \& Bonney, 2017; Järvinen \& Karjaluoto, 2015; Lassala, Carmona, \& Momparler, 2016; Straker \& Wrigley, 2016; T. Thomas, 2015; Walmsley, 2016; W.-L. Wang, Malthouse, Calder, \& Uzunoglu, 2017)

The objective of this study would be synthesis the new- research model to fulfilling the research gap between the role of human resources within customer value delivered and innovative behavior that supported by the newest technologies on the national- hi-tech firms to the digitalize e- market and its impact on the financial performance and the trust such as a moderating as a supporting variable within a new model. Furthermore, the focus of an intervening variables as digitalize emerging- market and incremental innovation within a synthesis of results base on the focused of value creation and the trust such as moderating impact to.(Demirkan \& Spohrer, 2014; Geraerdts, 2012; Järvinen \& Karjaluoto, 2015; Kianto, Sáenz, \& Aramburu, 2017; Kim, Cavusgil, \& Cavusgil, 2013; Landroguez, 2013; Li, 2010; Malik, Pereira, \& Budhwar, 2017; Matošková \& Směšná, 2017; Obal \& Lancioni, 2013; Senichev, 2013; Stone, Deadrick, Lukaszewski, \& Johnson, 2015; Walmsley, 2016; Xerri \& Reid, 2017)

The human resources within the value creation on an among multi- national- hi-tech corporations have many strategic plan to enhance the financial performance, and radically inventions- competitively within good manage for winning the competition, the transformational leadership, the human resources- advantage and would pursue the good digitalized emerging market on among multi-national market for having the new- opportunity for the business within create unique value on among consumers. Moreover, the strategic choices have an important way to applied by managers for improvement firm performance within well transformational leadership within the consumer trust as the moderating latent variable. (R. T. Hamilton, 2011; Reid \& Brady, 2012) (Poisson-de Haro \& Bitektine, 2015; Z. Wang, Sharma, \& Cao, 2016).

Hence, an entire multi- national hi-tech firms should have the digital customer engagement to create knowledge network for the relations between digital channel and an end-user, on the multi- national venture in the digitalize era to pursuing the financial performance and its effect within the trust as the moderating to make the strengthening impact.(Fang, Wang, \& Chen, 2017; Ghosh \& Wu, 2012; Gupta \& Polonsky, 2014; Yu, Ramanathan, \& Nath, 2013) (Anselmsson \& Bondesson, 2015; Ben Aissa \& Goaied, 2016; C. Roach, Ryman, \& White, 2014; Takata, 2016)

\section{Literature review and the Hypothesis}

The study was inquiry the research- model on conducted within the contributions for the body of knowledge on R-A Theory, GST and GOF for the competitions and holistic, also for the contributions in develop of the management implications to make the strategies within entire multi- national firms. 
Moreover, in this study within the R-A Theory, GST and GOF for pursuing the robust competitiveness advantage to affected the superior financial performance in multi-national hi-tech business.

The Resource- Comparative Advantage Theory, Theory of the growth of Firms in Industrial enterprise and the Contributions on Body of Knowledge

The Resources- comparative advantage theory have some knowledge about competition among venture in heterogeneous industries for long-run business development, and the sustainable competitive advantage should have as the foundation of the enterprise to planning the structures, bundles and provide the top-organization's resources and it's have smart- management winning the competitions for lung-run business within hybrid competitive strategy for achieving the financial performance.(Gabrielsson, Seppälä, \& Gabrielsson, 2016; Shelby D. Hunt, 2013, 2015; Shelby D Hunt \& Morgan, 1995; Zhao, Feng, \& Wang, 2015)

The scholar was mentions to the grand theory to fulfill the research gap and its was make the contribution for the body of knowledge and gain the novelty result from the results of an empirical research as follow, the figure 1 below:

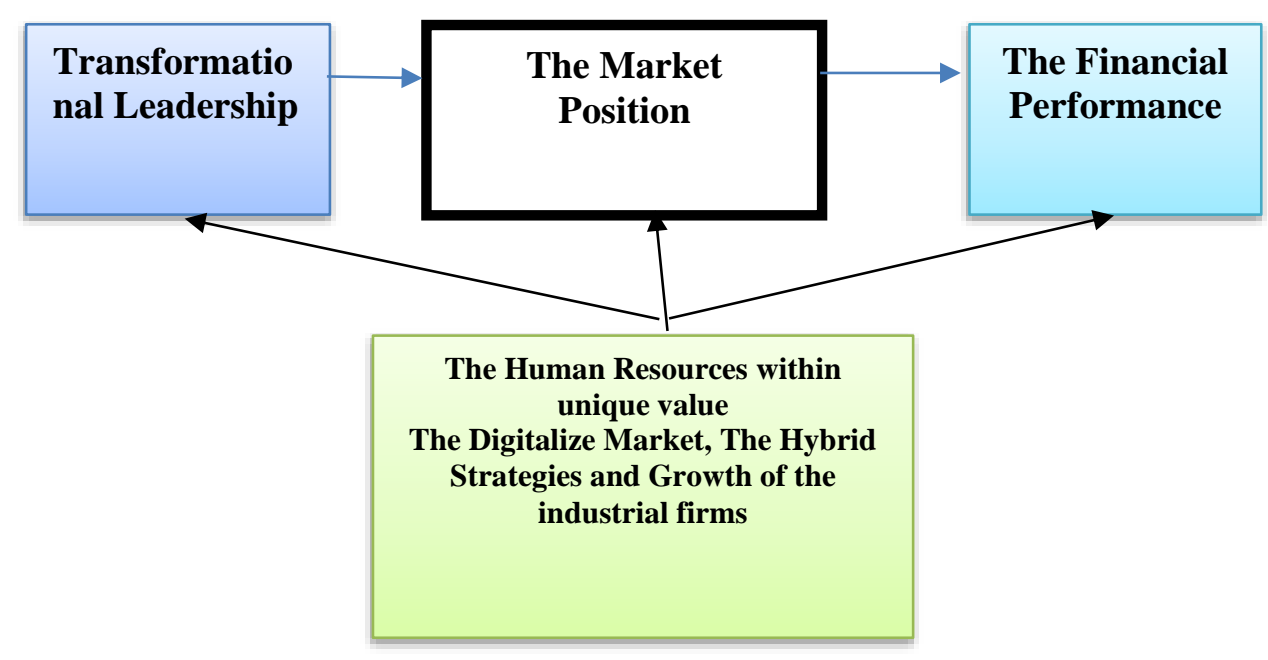

Figure 1. The R-A Theory and the industrial Firms and the Path to Contributions on Body of Knowledge

\section{The Framework and Hypothesis}

Indeed, the research framework of Superior- Financial Performance within MultinationalCorporations should have for development to fulfillment the research gap for finding the knowledge 
to increase the superior- financial performance within heterogeneous industries and contributions for R-A Theory, GST and GOF in the body of knowledge within the management science (Shelby D. Hunt, 2013, 2015; Shelby D. Hunt \& Arnett, 2006).

Moreover, the theory of the growth of firms in industrial hi-tech enterprise are could conducted to have the long-run business and sustainable and analysis of heterogeneously industries and economic functions, transformational leadership, consumer trust, an organizing human resource and other resource to gain the good profitability also deliver product with well administrative coordination and tight communication within among the industrial hi-tech firms. Hence, the market action, competitive advantage and performance should be based for making the action plan for run the sustainability business. (Castaño, Méndez, \& Galindo, 2016; Demirkan \& Spohrer, 2014; Kapferer, 2012; Torun \& Çicekci, 2007).

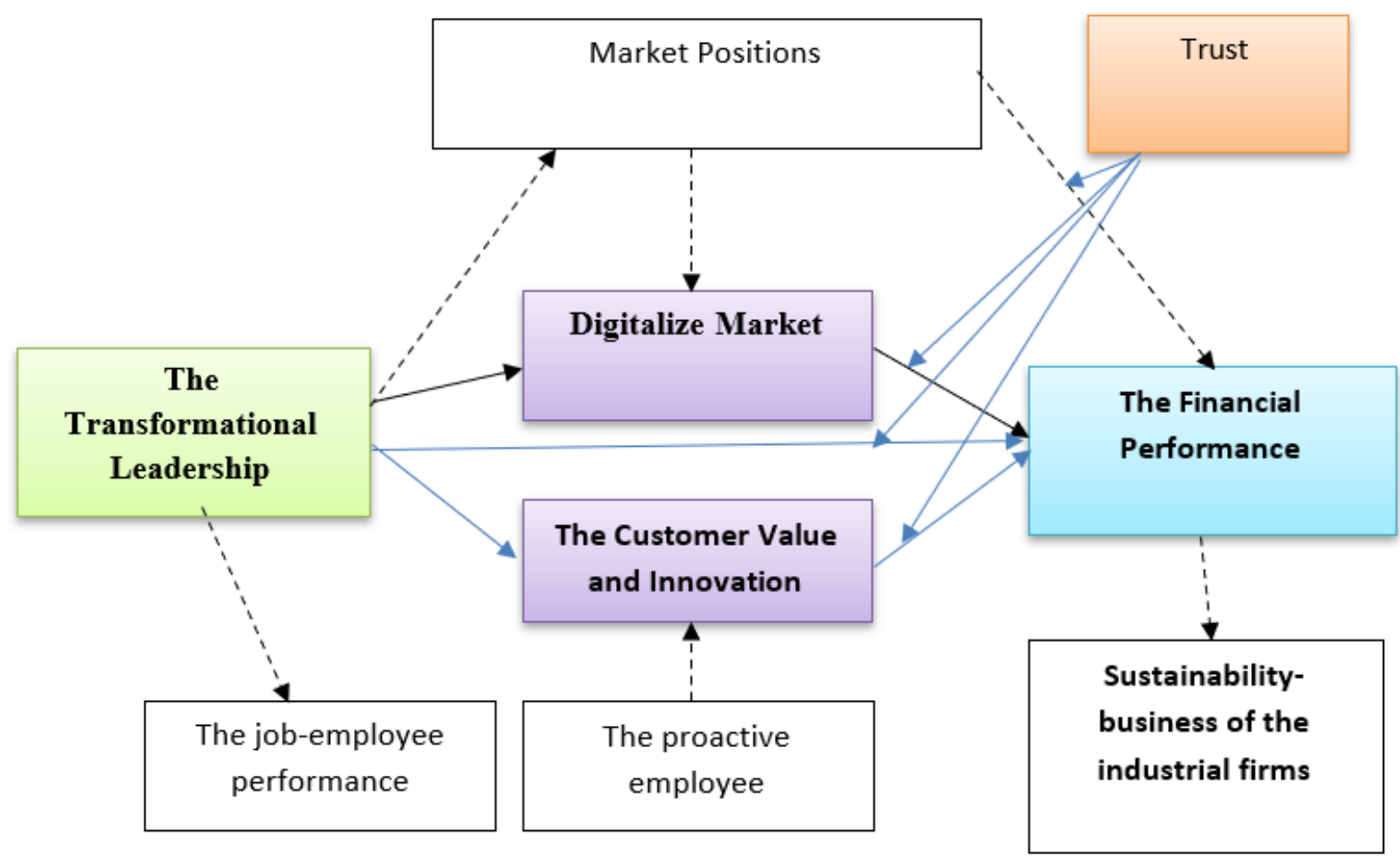

Fig.2. The Research Model enhancing the financial performance in Hi-Tec Corporate (Source: Develop from an Author- concept) 


\section{RESEARCH METHOD}

The quantitatively method was conduct in this study with research design of the survey and the sample and data collection, the respondent in digital era as which participated that daily used the consumers good which have the newest technology- product within total sampling (Mathwick, Wagner, \& Unni, 2010; E. Thomas, 2013). The data would be collected from in JABODETABEK industrial estate, which used the national- hi-tech product and in this study conducted within an area sampling that it selected by researcher within matching criteria (Sekaran U and Bougie R (2016).

Measurement of variables, the inquiry was conduct to the self-administered questionnaire of the rating scale for among latent variables and to make the response that they were use the newest technologies consumers goods (Sekaran U and Bougie R (2016). Moreover, the tools- instrument have the independently cross-sectional collected method and conducted with the rating scale as an interval data scale (1 to 10 very agree). Hence, the validity and reliability construct test that conducted with measurement model in structural equation modeling among variables (Hair, Black, Babin and Anderson, 2010).

\section{Data analysis, The Model of Fitting and Hypothesis testing}

The quantitative data analysis, the data analysis would conduct to the structural equation modeling, because entire the variables were latent characteristics within the smartPLS, as follow figure 3 such as first assessments data: The hypothesis in these inquiries the conceptual research model on figure 2 above, as follow:

H1. The transformational leadership is positively related to develop digitalize market and financial performance within industrial hi-tech firms.

H2. The develop digitalize market and customer value within industrial hi-tech firms is positively related to the superior financial performance conduct to the consumer trust as the moderating variable. 


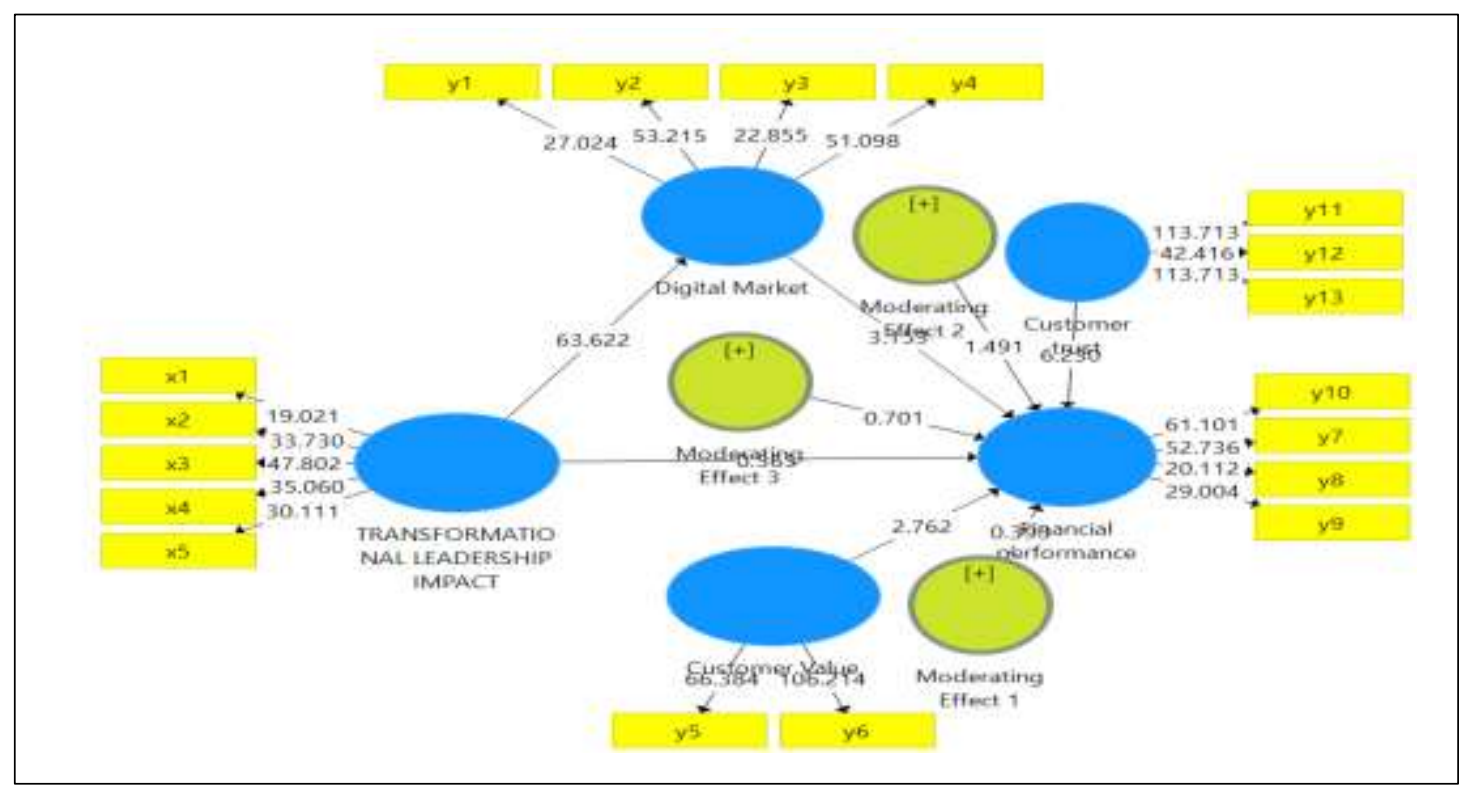

\section{Fig.3. The Research Predicting New-Model enhancing the financial performance in Hi-Tec Corporate}

Hence, the one step approach have pertains; the outer model use to validation and reliably assessments among parameter's and the structural hybrid full model as the inner model development and used the prediction strategies were conducted in this multivariate quantitative- data analysis, with a testing the validity and the reliability construct, also synthesis the fitting model and hypothesis proved (Susilo and Yulius, 2017). The research result would have for the data analysis pertain: the sensitivity analysis: the test indicated did not have the outlier and missing value that conducted with SPSS and the $\mathrm{z}$ value $<2.50$ and a univariate and multivariate of normality test. Hence, the Model of Fitting and Hypothesis testing, the goodness of fit research model could be analyzed within the indexed value. Moreover, the entire hypothesis confirmed was conducted with $t$ value $>2$ and $p$ value less than 0.05 .

\section{CONCLUSIONS AND RESEARCH CONTRIBUTION.}

Conclusions, the research result will successfully to confirm among hypotheses, and the greatest value can find to pursue financial performance multi-national hi-tech corporations. The researcher hopes the fulfillment the research gap within the new research model to achieve the financial performance within superior categories. Research contribution, the research contributions were within 2 (two) area that pertain; first, the contributions for theoretical implications to the body of knowledge of the recourses advantage, market position and the financial performance of the multi-national hi-tech venture. Moreover, the conducted with R-A theory, GST and GOF as the explanations and predicted also the theory of the growth of the firm to the confirmatory for the attempt the financial performance that its 
Vol. 3, No. 06 Nov-Dec; 2021 Page. No. 83-92

will investigate on the market- based research in management that it conduct the latent consumer trust as the moderating variable.

\section{Acknowledgement}

Thank you so much to Doctorate Multivariate class and the New Expertise and Experience Learning Club, Faculty of Economic and Business, University of Persada Indonesia Y.A.I. To my colleague and students. To in Kind Workshops The NEW- E\&EL CLUB LABORATORY FEB UPI Y.A.I team. Declaration of conflicting interests

The scholar declared no potential conflicts of interest with respect to the investigated, authorship, publication within this manuscript.

\section{Funding}

The authors did not receive the financial support for this research and publication of this manuscript. ORCID:000-0002-6758-1159, URL: orcid.org/0000-0002. And SCOPUS ID: 56539508300.

\section{REFERENCES}

Anselmsson, J., \& Bondesson, N. (2015). Brand value chain in practise; the relationship between mindset and market performance metrics: A study of the Swedish market for FMCG. Journal of Retailing and Consumer Services, 25, 58-70. doi: 10.1016/j.jretconser.2015.03.006

Ben Aissa, S., \& Goaied, M. (2016). Determinants of tourism hotel market efficiency. International Journal of Culture, Tourism and Hospitality Research, 10(2), 173-190. doi: 10.1108/IJCTHR11-2013-0080

Bitter, S., \& Grabner-Kräuter, S. (2016). Consequences of customer engagement behavior: when negative Facebook posts have positive effects. ElectronMarkets, 26, 13.

Bürkner, H.-J., \& Lange, B. (2017). Sonic capital and independent urban music production: Analysing value creation and 'trial and error' in the digital age. City, Culture and Society. doi: 10.1016/j.ccs.2017.04.002

C. Roach, D., Ryman, J., \& White, J. (2014). Culture, conduct and innovation: a deconstruction of market orientation. Journal of Research in Marketing and Entrepreneurship, 16(2), 128-145. doi: 10.1108/JRME-01-2014-0002

Castaño, M. S., Méndez, M. T., \& Galindo, M. Á. (2016). The effect of public policies on entrepreneurial activity and economic growth. Journal of Business Research, 69(11), 52805285. doi: 10.1016/j.jbusres.2016.04.125

Darren, D. (2015). Behavioral finance: insights from experiments I: theory and financial markets. Review of Behavioural Finance, 7(1), 78-96. doi: 10.1108/RBF-03-2015-0011

Demirkan, H., \& Spohrer, J. (2014). Developing a framework to improve virtual shopping in digital malls with intelligent self-service systems. Journal of Retailing and Consumer Services, 21(5), 860-868. doi: 10.1016/j.jretconser.2014.02.012 
Vol. 3, No. 06 Nov-Dec; 2021 Page. No. 83-92

Fang, S.-C., Wang, M.-C., \& Chen, P.-C. (2017). The influence of knowledge networks on a firm's innovative performance. Journal of Management \&\#x0026; Organization, 23(1), 22-45. doi: 10.1017/jmo.2016.32

Gabrielsson, M., Seppälä, T., \& Gabrielsson, P. (2016). Realizing a hybrid competitive strategy and achieving superior financial performance while internationalizing in the high-technology market. Industrial Marketing Management, 54, 141-153. doi: 10.1016/j.indmarman.2015.07.001

Geraerdts, R. (2012). Customer value creation: A journey in the search of excellence. Industrial Marketing Management, 41(1), 11-12. doi: 10.1016/j.indmarman.2011.11.023

Ghosh, D., \& Wu, A. (2012). The Effect of Positive and Negative Financial and Nonfinancial Performance Measures on Analysts' Recommendations. Behavioral Research in Accounting, 24(2), 47-64. doi: 10.2308/bria-10283

Glińska-Neweś, A., Sudolska, A., Karwacki, A., \& Górka, J. (2017). INNOVATIONS AMONG PEOPLE. HOW POSITIVE RELATIONSHIPS AT WORK CAN TRIGGER INNOVATION CREATION. E+M Ekonomie a Management, 20(3), 84-100.

González, L. O., Rodríguez Gil, L. I., Martorell Cunill, O., \& Merigó Lindahl, J. M. (2016). The effect of financial innovation on European banks' risk. Journal of Business Research, 69(11), 47814786. doi: 10.1016/j.jbusres.2016.04.030

Graça, S. S., Barry, J. M., \& Doney, P. M. (2016). B2B commitment building in emerging markets: the case of Brazil. Journal of Personal Selling \& Sales Management, 36(2), 105-125. doi: 10.1080/08853134.2016.1188708

Gupta, S., \& Polonsky, M. (2014). Inter-firm learning and knowledge-sharing in multinational networks: An outsourced organization's perspective. Journal of Business Research, 67(4), 615622. doi: 10.1016/j.jbusres.2013.02.043

Haifen, L., Mengya, C., \& Jingqin, S. (2017). How management innovations are successfully implemented? An organizational routines' perspective. Journal of Organizational Change Management, 30(4), 456-486. doi: 10.1108/JOCM-07-2016-0124

Hamilton, J. (2009). Building a targeted pharmacy customer engagement approach. International Journal of Pharmaceutical and Healthcare Marketing, 3(4), 381-396.

Hamilton, R. T. (2011). How firms grow and the influence of size and age. International Small Business Journal, 30(6), 611-621. doi: 10.1177/0266242610383446

Harrigan, P., Evers, U., Miles, M. P., \& Daly, T. (2017). Customer engagement and the relationship between involvement, engagement, self-brand connection and brand usage intent. Journal of Business Research. doi: 10.1016/j.jbusres.2017.11.046

Hau, L. N., Evangelista, F., \& Thuy, P. N. (2013). Does it pay for firms in Asia's emerging markets to be market oriented? Evidence from Vietnam. Journal of Business Research, 66(12), 24122417. doi: 10.1016/j.jbusres.2013.05.028

Ho, K. L. P., Nguyen, C. N., Adhikari, R., Miles, M. P., \& Bonney, L. (2017). Exploring market orientation, innovation, and financial performance in agricultural value chains in emerging economies. Journal of Innovation \& Knowledge. doi: 10.1016/j.jik.2017.03.008

Hollebeek, L. D. (2012). The customer engagement/value interface: An exploratory investigation. Australasian Marketing Journal (AMJ). doi: 10.1016/j.ausmj.2012.08.006 
Vol. 3, No. 06 Nov-Dec; 2021 Page. No. 83-92

Hunt, S. D. (2013). A general theory of business marketing: R-A theory, Alderson, the ISBM framework, and the IMP theoretical structure. Industrial Marketing Management, 42(3), 283293. doi: 10.1016/j.indmarman.2013.02.002

Hunt, S. D. (2015). Marketing theory : foundations, controversy, strategy, resource-advantage theory. New York, USA: Routledge Taylor \& Francis Group.

Hunt, S. D., \& Arnett, D. B. (2006). Does marketing success lead to market success? Journal of Business Research, 59(7), 820-828. doi: 10.1016/j.jbusres.2006.01.019

Hunt, S. D., \& Morgan, R. M. (1995). The comparative advantage theory of competition. The Journal of Marketing, 1-15.

Järvinen, J., \& Karjaluoto, H. (2015). The use of Web analytics for digital marketing performance measurement. Industrial Marketing Management. doi: 10.1016/j.indmarman.2015.04.009

Kapferer, J.-N. (2012). Abundant rarity: The key to luxury growth. Business Horizons, 55(5), 453462. doi: 10.1016/j.bushor.2012.04.002

Kianto, A., Sáenz, J., \& Aramburu, N. (2017). Knowledge-based human resource management practices, intellectual capital and innovation. Journal of Business Research, 81, 11-20. doi: 10.1016/j.jbusres.2017.07.018

Kim, D., Cavusgil, S. T., \& Cavusgil, E. (2013). Does IT alignment between supply chain partners enhance customer value creation? An empirical investigation. Industrial Marketing Management, 42(6), 880-889. doi: 10.1016/j.indmarman.2013.05.021

Landroguez, S. M. (2013). Developing an integrated vision of customer value. Journal of Services Marketing, 27(3), 234-244. doi: 10.1108/08876041311330726

Lassala, C., Carmona, P., \& Momparler, A. (2016). Alternative paths to high performance of independent financial advisors: A fuzzy-set analysis. Journal of Business Research, 69(11), 5305-5309. doi: 10.1016/j.jbusres.2016.04.129

Li, Y.-M. (2010). Pricing digital content distribution over heterogeneous channels. Decision Support Systems, 50(1), 243-257. doi: 10.1016/j.dss.2010.08.027

Malik, A., Pereira, V., \& Budhwar, P. (2017). Value creation and capture through human resource management practices. Organizational Dynamics. doi: 10.1016/j.orgdyn.2017.09.002

Mathwick, C., Wagner, J., \& Unni, R. (2010). Computer-Mediated Customization Tendency (CMCT) and the Adaptive e-Service Experience. Journal of Retailing, 86(1), 11-21. doi: 10.1016/j.jretai.2009.11.001

Matošková, J., \& Směšná, P. (2017). Human resource management practices stimulating knowledge sharing. Management \& Marketing, 12(4). doi: 10.1515/mmcks-2017-0036

Obal, M., \& Lancioni, R. A. (2013). Maximizing buyer-supplier relationships in the Digital Era: Concept and research agenda. Industrial Marketing Management, 42(6), 851-854. doi: 10.1016/j.indmarman.2013.06.002

Poisson-de Haro, S., \& Bitektine, A. (2015). Global sustainability pressures and strategic choice: The role of firms' structures and non-market capabilities in selection and implementation of sustainability initiatives. Journal of World Business, 50(2), 326-341. doi: 10.1016/j.jwb.2014.10.009

Reid, M., \& Brady, E. (2012). Improving firm performance through NPD: The role of market orientation, NPD orientation and the NPD process. Australasian Marketing Journal (AMJ), 20(4), 235-241. doi: 10.1016/j.ausmj.2012.05.011 
Vol. 3, No. 06 Nov-Dec; 2021 Page. No. 83-92

Senichev, V. (2013). Human Resource Diversity and Performance within the Frame of Organizations, Teams and Individuals. Verslas: teorija ir praktika, 14(4), 337-345. doi: 10.3846/btp.2013.36 Shelby, D. H. (2007). Economic growth: should policy focus on investment or dynamic competition? European Business Review, 19(4), 274-291. doi: 10.1108/09555340710760116

Stone, D. L., Deadrick, D. L., Lukaszewski, K. M., \& Johnson, R. (2015). The influence of technology on the future of human resource management. Human Resource Management Review, 25(2), 216-231. doi: 10.1016/j.hrmr.2015.01.002

Straker, K., \& Wrigley, C. (2016). Designing an emotional strategy: Strengthening digital channel engagements. Business Horizons, 59(3), 339-346. doi: 10.1016/j.bushor.2016.01.010

Takata, H. (2016). Effects of industry forces, market orientation, and marketing capabilities on business performance: An empirical analysis of Japanese manufacturers from 2009 to 2011. Journal of Business Research. doi: 10.1016/j.jbusres.2016.03.068

Thomas, E. (2013). Supplier integration in new product development: Computer mediated communication, knowledge exchange and buyer performance. Industrial Marketing Management, 42(6), 890-899. doi: 10.1016/j.indmarman.2013.05.018

Thomas, T. (2015). Agent-based risk management - a regulatory approach to financial markets. Journal of Economic Studies, 42(5), 780-820. doi: 10.1108/JES-03-2013-0039

Torun, H., \& Çicekci, C. (2007). INNOVATION: IS THE ENGINE FOR THE ECONOMIC GROWTH? Research Paper.

Vivek, S. D., Beatty, S. E., \& Morgan, R. M. (2012). Customer Engagement: Exploring Customer Relationships Beyond Purchase. Journal of Marketing Theory and Practice, 20(2), 122-146. doi: 10.2753/MTP1069-6679200201

Walmsley, B. (2016). From arts marketing to audience enrichment: How digital engagement can deepen and democratize artistic exchange with audiences. Poetics, 58, 66-78. doi: 10.1016/j.poetic.2016.07.001

Wang, W.-L., Malthouse, E. C., Calder, B., \& Uzunoglu, E. (2017). B2B content marketing for professional services: In-person versus digital contacts. Industrial Marketing Management. doi: 10.1016/j.indmarman.2017.11.006

Wang, Z., Sharma, P. N., \& Cao, J. (2016). From knowledge sharing to firm performance: A predictive model comparison. Journal of Business Research, 69(10), 4650-4658. doi: 10.1016/j.jbusres.2016.03.055

Xerri, M. J., \& Reid, S. R. M. (2017). HUMAN RESOURCES AND INNOVATIVE BEHAVIOUR: IMPROVING NURSING PERFORMANCE. International Journal of Innovation Management, 1850019. doi: 10.1142/S1363919618500196

Yu, W., Ramanathan, R., \& Nath, P. (2013). The impacts of marketing and operations capabilities on financial performance in the UK retail sector: A resource-based perspective. Industrial Marketing Management. doi: 10.1016/j.indmarman.2013.07.014

Zhao, G., Feng, T., \& Wang, D. (2015). Is more supply chain integration always beneficial to financial performance? Industrial Marketing Management, 45, 162-172. doi: 10.1016/j.indmarman.2015.02.015 